International Journal of Current Advanced Research

ISSN: O: 2319-6475, ISSN: P: 2319 - 6505, Impact Factor: 5.995

Available Online at www.journalijcar.org

Volume 6; Issue 3; March 2017; Page No. 2411-2420

DOI: http://dx.doi.org/10.24327/ijcar.2017.2420.0019

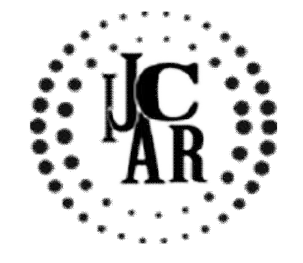

Research Article

PROFESSIONALISM WOMEN IN PUBLIC SERVICE IN IMMIGRATION CLASS II BUKITTINGGI

\title{
Agussalim M*
}

Management Program Studies, Faculty of Economics, Ekasakti University, Padang Indonesia

\section{A R T I C L E I N F O \\ Article History: \\ Received $10^{\text {th }}$ December, 2016 \\ Received in revised form $4^{\text {th }}$ January, 2017 \\ Accepted $12^{\text {th }}$ February, 2017 \\ Published online $28^{\text {th }}$ March, 2017}

\section{Key words:}

Professionalism Women and Public Service

\begin{abstract}
A B S T R A C T
This research is motivated by the involvement of women in public life as a public service that provides services to people who are required to work professionally in a manner that reflected the everyday in the organization, particularly at the immigration office class II Bukittinggi. The goal is to find out how the professionalism of women in public service and know the obstacles faced by women in the public service as well as the efforts made to overcome these obstacles. The research method is a method of qualitative deskiptif present data, analyze and interpret, which is comparative and correlative, relating to the object of research as well as trying to explain and describe the variables in depth and detail with the objectives that have been formulated. Data from the questionnaires were analyzed through frequency distribution table and analyzed according to the respondents, in this case the number of respondents 45 people from the community and interviews with seven people from the immigration office employee class II Bukittinggi. The research concludes that the professionalism of female employees at the Immigration Office Class II Bukittinggi can be said to be excellent with a contribution of $84.4 \%$, of the respondents who stated that the readiness of employees in the implementation of the service that is disciplined in starting and completing the service, capable of doing the job which it is responsible, the attitude of employees in providing services to the public. Where employees work to understand and implement well the role, duties and responsibilities in matters regarding immigration, but in reality there were limited both from internal factors and external factors. Therefore, efforts to overcome these obstacles in order to improve the performance of women is concerned thus, it will also affect the improvement of services at the Immigration office class II Bukittinggi.
\end{abstract}

Copyright $(2017$ Agussalim M. This is an open access article distributed under the Creative Commons Attribution License, which permits unrestricted use, distribution, and reproduction in any medium, provided the original work is properly cited.

\section{INTRODUCTION}

Development in Indonesia is intended to realize the national ideal, which is to protect the whole Indonesian nation, promote the general welfare and educating the nation. Rapid national development in all areas of the reform era requires a reliable workforce. This means that workers can pass on the sustainability of national development through the improvement of existing human resources in a professional manner.

Speaking about professionalism, it reflects one's attitude toward his profession. Simply put professionalism is defined as a behavior, manner and quality that characterize a profession. Someone said to professionals if their work has the characteristics of a technical or ethical standards of a profession (LIPI, 2015). The human resources of the organization has a variety of characteristics, including the ability/professionalism, motivation and performance it has.

\footnotetext{
*Corresponding author: Agussalim M

Management Program Studies, Faculty of Economics, Ekasakti University, Padang Indonesia
}

The three components are closely related and are in selfemployees who carry out everyday tasks. So the ability or human resources is very important, especially in women, particularly as it continues to experience growth, there are also many women problems especially in women acknowledge it in place.

Regardless of the controversy, Indonesia seeks to enhance the role and position of women as mandated guidelines in 1999 that the construction of the empowerment of women is gender equity and equality in family life, community, nation, and state. This shows that the government through its policies are still considered it necessary to interpret the role and position of women in development (Horeapoetri, 2004).

The participation of women regarding the role of traditions and transitions, tradition or domestic Roles include the role of women as wives, mothers, and the manager of the household. Mean while, the role of women transition including the understanding of women as workers, community members and development. Transitional role of women can not be separated from the factors that influence such as their motivation, a strong desire to actualize themselves, their 
beliefs and positive things that can give you success and certainly can help the family economy as well as having its own financial autonomy. However, undergoing two roles at once as a worker and housewife is not easy. This brings the two roles conflict prolonged clash between responsibilities as a housewife and responsibilities as workers.

The involvement of women in the public sphere as a public service that provides services to people who are required to professionals in the work of those in the mission, carry out the functions and carry out all the activities that are the responsibility, with a level of efficiency, high effectiveness, coupled with service orientation is not the orientation of power and displays the functional behavior.

According to Kotler (2002), that service is any activity which is advantageous in a gathering or unity and offer satisfaction even though the results are not tied to a physical product. Furthermore, because the service is an activity or sequence of events that occur in the direct interaction between a person with another person or machine physically and provide customer satisfaction.

Immigration Office Class II Bukittinggi is a Government Agency under the auspices of the Directorate General of Immigration is responsible directly to the Ministry of Justice and Human Rights of the Republic of Indonesia. Immigration Class II Bukittinggi is a community service office or on duty called UPT (Technical Implementation Unit) whose task is to directly confront or serving the community, especially in the City of London, where the immigration office in Bukittinggi clearly has a very important role. Especially in terms of service to the public in handling matters such as travel documents, visas and facilities, residence permits and status, intelligence, investigation, and enforcement, cross-border and overseas cooperation and information systems immigration.

Progress and success of the bureaucrats of women in the field of immigration service relies heavily on the performance of female employees itself, where women are able to work hard, proactive, loyal and disciplined and responsible tasks and jobs that can ultimately achieve optimal performance thus have a positive impact on performance bureaucracy. But in fact still found difficulties associated with the performance of bureaucrats women at the Immigration office class II London, the constraint can not be separated from the behavior of the organization to the work, whether it came from within and outside the organization, resulting in fewer dedication, creativity, motivations, and ideals of the profession, The demands of work associated with the pressure that comes from the workload is excessive and time as the work to be completed in a hurry and deadlines, besides the presence of negative culture as their laziness take the initiative outside of regulation, the strong tendency to wait Tops, slow in giving services, lack of motivation of the leadership, the inner atmosphere and mood that sometimes change so that the quality of service bureaucrats poor women.

Based on these problems, the authors are interested in doing a study entitled "The professionalism of Women in Public Service In Singapore Immigration Class II".

\section{Research purposes}

The purpose of this study are:
1. To find out the Women in Public Service Professionalism in the Office of Immigration Class II Bukittinggi.

2. To find out the obstacles encountered Professionalism Women in Public Service Immigration Office Class II Bukittinggi.

3. To know the efforts made to overcome the obstacles encountered Professionalism Women in Public Service Immigration Office Class II Bukittinggi.

\section{LITERATURE REVIEW}

\section{Professionalism Women}

Professionalism comes from the word professional meaningful work performed as principal activity to generate a livelihood and who rely on the skills. Professionalism can be defined as the ability and skill to do the job according to the field and the level of each. In a large dictionary Indonesian professionalism has meaning: quality, quality, and behavior that is the attitude of a professional.

According to Kurniawan (2005), Professionalism involves a match between the capabilities of the bureaucracy to the task needs, unmet match between capabilities with the needs of the task is a condition of the formation of professional personnel. This means that the expertise and capacity of the reflecting direction and objectives to be achieved by an organization ".

While the sense of professionalism according to the Ministry of the Interior is the reliability in performing the tasks so done with high quality, timely manner, accurately and with procedures that are easily understood and followed by the customers. According Imawan (1997), the professionalism shown the work in accordance with the technical standards or ethics of a profession. Work activity commonly associated with income in the form of money.

To create a level of professionalism in carrying out the requirements of the institution's mission basically is the availability of qualified human resources, a job well programmed, and the time available to implement the program and the support of adequate funds and facilities support.

According to the definition in the Dictionary of Indonesian Language mentioned, women are those (men) who can menstruation, pregnancy, childbirth and breastfeeding.

Syafiq $(5 ; 2005)$ defines by discreet, in this world that is recognized as a human being "normal" human sex is male and female. Although the title as a human being "normal", but there is inequality between the two, repression (repression) is truly extraordinary. Men dominate women in various fields of life. Women are being gentle and loving because she felt fine. In general, the nature of women, the beauty, gentleness and humility and maintain. Thus the image of women that is often heard around us. Differences in anatomical and physiological causes are also differences in their behavior, and the resulting differences in terms of ability, selectively to activities aimed intentional and purposeful with the nature of women.

While Kartini Kartono in Mansour (2005) said, that the natural physiological differences at birth are generally reinforced by the structure of the existing culture, especially by customs, socio-economic system and influence of education. 
Based on the description that the previous writer explained above, the authors conclude that women are physiologically experienced since birth that is reinforced by the structure of the culture in which sex differences did not lead to differences in talent between both.

Professionalism women is largely determined by the level of ability of women themselves reflected through his behavior the day - a day in the organization. Professionalism women in department of Interior and according Sianipiar female professionalism is the ability or aptitude in providing services as a state apparatus that are tailored to the knowledge of the field and the task in hand.

According to Kurniawan (2005), the professionalism of women is a natural trait possessed in carrying out the profession or occupation that is adjusted to the time and the cycle of jobs that have been set by the organization. According to Supriya, the professionalism of women is the degree of performance refers to the attitude and commitments were always held in high esteem on a code of ethics that embrace the organization.

Based on the sense of professionalism of women above, can the authors conclude that the professionalism of women is the ability and talents of a woman in providing services to people who refer to the attitude and commitment of the profession to work on time and cycle work, so that it can be reflected in his behavior a day - day in organizations.

\section{Basic Principle of Professionalism}

According to H. Sumitro Maskun (1997), that a professional is a form or field of activity that can provide services with specialization and high intellect. Form or field of activity is in the practice of his achievements running three basic principles, namely:

1. The presence of a knowledge base that can be studied carefully and the presence of the attitude of the person who mastered the technique is also something that can be used in providing services to the public.

2. The success achieved by the profession, the standard size is how we finish fast service to the community and not what a person can achieve for their personal use.

3. The development of a monitoring system for the business and the practical activities of the professionals in the practice of education with the knowledge and results through the establishment of associations or associations and the creation of various codes of conduct.

The first step that must be taken for someone to status as a professional is to have sufficient intellectual capacity, which is a capability to be able to easily understand, understand, learn and explain the phenomenon.

\section{Professional Development Efforts}

In developing professionalism in the bureaucracy in Indonesia by Sumitro Maskun H. (1997), to consider the two aspects, namely:

1. Aspects of professional education is a form of education that can prepare students to handle the socalled professionals. So there is a relationship between the jobs held by someone with education selected or prepared.
2. Their planned recruitment process, supported by a system of career and development. Employee recruitment in Indonesia bureaucratic apparatus has not really oriented toward the working professional.

\section{Characteristics Professionalism}

According Mertin Jr. in Kurniawan (2005), characteristic of the professionalism of the apparatus in accordance with the demands of good governance, including:
1. Equality
2. Equity
3. Loyalty
4. Accountability

\section{Public Service}

Basically, every human being in need of service, even in the extreme can be said that the service is indispensable to human life. Budiman Rusli in Lijan et al (2006), found during his lifetime, people are always in need of service. Services thinks fit with the life cycle theory of leadership (LCTL) that at the beginning of human life (baby) services are physically very high, but as a person ages services required will decrease.

In the dictionary of the Indonesian ministry described it as, how, or employment outcomes airport. While the airport is regaled people with food or drinks, provided for the needs of others, agreed, receive, use.

Lijan (2006), states that the public service is defined, pemberiaan services (airport) for the person or people who have an interest in the organization in accordance with the basic rules and procedures have been established.

Furthermore, the decision of the Minister of State for Administrative Reform (2003), gives the sense of public service and of all service activities carried out by the organizers of the public in an effort to meet the needs of service recipients and the implementation of the provisions of the laws and regulations.

The shape and nature of public service, according to Boediono (2003), must contain the joints: simplicity, clarity, certainty, security, openness, efficiency, economy, justice, and timeliness.

\section{Indicators of Public Services}

As according to the Lijan Fitzsimons et al argue that there are five indicators in the public service, namely:

1. Realibility characterized proper service delivery and true

2. Tangibles are characterized by the provision of adequate human resources and other resources

3. Responsiveness is characterized by a desire to serve customers quickly

4. Assurance that marked the level of attention to moral ethics and service.

5. Empathy marked degree of willingness to know the desires and needs of consumers.

\section{RESEARCH METHODOLOGY}

The research method used in this research is descriptive qualitative research methods used to solve or answer problems faced in the present situation. 
According to Best (2003), said to be a descriptive study research method that seeks to describe and interpret the objects according to what it is. Ali Hamid, a senior official said in the book the research was conducted by taking langahstep collection, classification, and analysis or processing of data, make conclusions and report with the main objective to create a picture of a situation objectively in a description of the situation.

The population in this study were all employees of the Immigration office class II Bukittinggi and the entire community served by female employees at the Immigration office class II Bukittinggi. Because the data service female employees are not by serviced by the Immigration Office Class II Bukittinggi then the population was regarded as the author of unlimited population (the population of which is not limited).

In determining the sample of the object of this study the authors using purposive sampling technique, for employees of grade II Bukittinggi Immigration Office, where the method of taking samples of specially selected members based on objective research. Thus, the sample for the immigration office employee class II Bukittinggi writers charge 7 (seven) people where samples that researchers think is of concern, and knowing the problems studied. The sample can be seen in the following table:

Table 1 Breakdown of Number of Sample Research

\begin{tabular}{clc}
\hline No. & \multicolumn{1}{c}{ Sample } & Total \\
\hline 1 & Head of Sub Division of & 1 \\
2 & Administration & 1 \\
3 & Head of Public Affairs & 1 \\
4 & Head of Human Resources & 1 \\
5 & Head of Sub Section Lantaskim & 1 \\
6 & officer Counters & 2 \\
& Officers Photo and Interview & 7 \\
\hline
\end{tabular}

As for the people who come to the office of Immigration Class II Bukittinggi authors use accidental sampling, the sampling technique based on chance, that anyone who by chance met with writers who have been served by female employees at the Immigration office class II Bukittinggi which can be used as a sample for the population is not limited (unlimited population) and if the person who found it willing to become a source of data.

In collecting data the authors receive from the data source that is the source of primary data and secondary data sources including questionnaires, observations, interviews, library research and documentation (Burhan, 2006).

The data source is divided into two primary data and secondary data.

1. Primary data is data obtained directly from respondents through the interview, questioner and observation.

2. Secondary data is data obtained from data collection techniques that support the primary data. In this research, the results of observations conducted by the authors as well as from the literature such as books, articles, papers, regulations, implementation instructions, other technical instructions that have reference with papers studied.

\section{Data analysis}

In the research is descriptive data analysis based on the results of the deployment questionnaire that has been analyzed through frequency distribution table. From the analysis of these frequencies will be described / interpreted by the author related to the research problem in depth.

The method used in this study, according to Sudjana (1998), is a qualitative analysis. This analysis is used to address the first problem which is to find out how the professionalism of women in the public service by using the statistical frequency distribution as follows:

1. Total Cumulative value greatest weight $\times$ weight $=$ Number of respondents largest measurement $=45 \times$ $5=225$

2. The cumulative value of the smallest weight $\times$ weight $=$ Number of respondents smallest measurement $=45 \times 1=45$

3. The percentage value $=225 / 225 \times 100 \%=100 \%$

4. The value of the smallest percentage $=45 / 225 \times$ $100 \%=20 \%$

5. Value range $=100 \%-20 \%=80 \%$

6. The value of interval $=80 \%: 5=16 \%$

By using the frequency distribution statistical calculations above, the assessment criteria of each variable used in this study, as follows:

Table 2 Assessment criteria

\begin{tabular}{cc}
\hline $\begin{array}{c}\text { interval } \\
\text { percentage }\end{array}$ & $\begin{array}{c}\text { Assessment } \\
\text { criteria }\end{array}$ \\
\hline $20-35$ & Very less \\
$31-51$ & Less \\
$52-67$ & moderate \\
$68-83$ & Good \\
$84-100$ & Very good \\
\hline
\end{tabular}

As for determining the most prominent indicator or dominant of professionalism of women in public service at the Immigration office Bukittinggi class II can be determined by add up entire answer questions/statements which are rated by the respondents from each of the indicators of the variables studied, with the following formula:

$I D=\frac{\sum I}{\sum T I}$

Based on the results of the formula above, then the highest percentage of each indicator that is expressed as an indicator of the most prominent or dominant.

\section{RESULTS AND DISCUSSION}

\section{Descriptive Analysis of Human Resources}

Human resources (HR) is very important in supporting organizational performance. In the implementation of a program is of course necessary to support the implementation program executing well. Therefore, the availability of sufficient and competent executor in encouraging the success of a program is needed. To know the state of personnel resources to the Office of Immigration Class II Bukittinggi based on gender can be seen in the following table: 
Table 3 Characteristics of Employees by Sex

\begin{tabular}{cccc}
\hline No & Gender & Total & Percentage \\
\hline 1 & Man & 24 & $65 \%$ \\
2 & female & 13 & $35 \%$ \\
& Total & 34 & $100 \%$ \\
\hline \multicolumn{2}{l}{ Source: Personnel Data Immigration Class II London 201 }
\end{tabular}

IV.1 from the table above can be seen the number of personnel resources to the Office of Immigration Class II Bukittinggi, seen from the male gender 24 people $(65 \%)$ and 13 women $(35 \%)$. It is highly influential in the management of work that are more in need of physical power is strong enough, it can be seen from the table above that a male employee at the Immigration Office Class II Bukittinggi is more dominant than the female employee.

As we know that the background and a person's education level affects the knowledge and understanding of the duties and responsibilities. Distribution of $\mathrm{HR}$ man at the Immigration Office Class II Bukittinggi based education can be seen in the table below:

Table 4 Characteristics Employees According to Education

\begin{tabular}{cc|cc}
\hline No & Education & Total & Percentage \\
\hline 1 & S2 & 1 & $2,7 \%$ \\
2 & S1 & 19 & $51,4 \%$ \\
3 & D 3 & 6 & $16,2 \%$ \\
4 & SLTA & 11 & $29,7 \%$ \\
& Total & 37 & $100 \%$ \\
\hline
\end{tabular}

Educational level of employees at the Immigration Office Class II Bukittinggi has the potential to have the knowledge and professional attitude to expand its services to the community, as well as the progressive increase in the knowledge and expertise to complete the formation of positions in order to improve the quality of services as to which is seen from Table 4, the number of employees with undergraduate education level (S1) the most 11 people, undergraduate education level (S2) with the number 1, undergraduate Diploma numbered 6 and the last high school as many as 11 people.

\section{RESULTS AND DISCUSSION}

\section{Professionalism Women in Public Service}

Based on the results of the questionnaire, the respondents to the professionalism of women in public service at the Immigration office Bukittinggi class II are as follows:

\section{Reliability}

The ability of female employees providing services to the public in accordance with the expected, such as the ability to keep promises, problem-solving skills and the ability to minimize errors.

In indicator Reliability/reliability owned female employees in the public service consists of four statements, from the statement resulted in answer respondents as in the table below:
Table 6 Reliability/expertise female employees

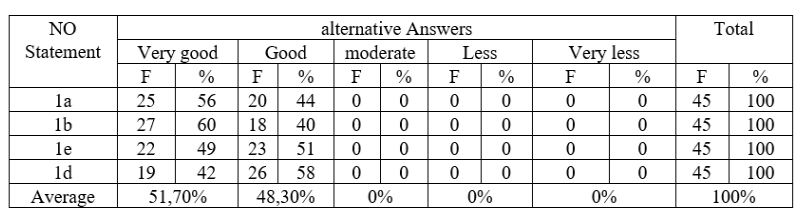

Source: processed data from excel 2007 Appendix 3

At No. 1a questions about the procedure or process of services provided to the public female employees is good it proved of respondents expressed very well by $55.6 \%$ and the rest give a statement both $44.4 \%$. For question No. $1 \mathrm{~b}$ of female employees provide thorough and reliable services to the people $60 \%$ said excellent and $40 \%$ said Good. In answer further questions $1 \mathrm{c}$ the public about female employees who provide service that is easy and straightforward to the public $48.9 \%$ stated very well and the rest declared either $51.1 \%$. it can be concluded that the service is easy and not complicated given kink female employees categorized Good. Then for questions $1 \mathrm{~d}$ on speed time female employees in serving the people categorized Well this is evidenced by the $42.2 \%$ declared Very Good and 57.8\% said Good.

Based on the statements that have been made can be concluded Professionalism involves women realibility or Reliability and expertise possessed female employees in the public service at the immigration office class II Bukittinggi can be said Very Good. In answer Aside from respondents on indicators of reliability / expertise of women in the public service of direct observations and interviews conducted by the authors, shows that in the process of service that is reliable, accurate, easy, not complicated - straightforward and correct their speed of service time.

\section{Tangible}

On this indicator consists of four questions about things that are visible in the services provided female employees in the public service, which results in table 5 respondents as follows:

Table 5 Things are seen in the Public Service

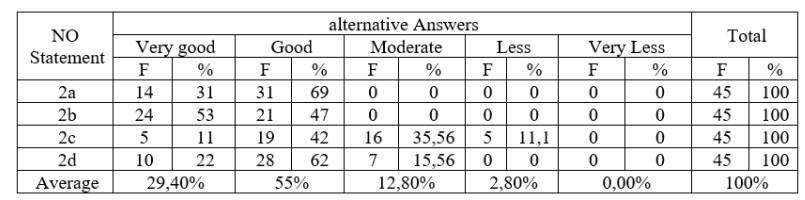

Source: processed data from excel 2007 Appendix 3

On question No. 2a of the shape of female employees service provided to the community as much as $31.1 \%$ stated Very Good, $68.9 \%$ said Good. So we can conclude that the form of services provided to the public female employees categorized good. 2b For questions about the clarity of the information provided to the public employee female respondents saying Very Good No 53.3\%, and the remaining 46.7\% declare Good, the conclusion of the question of $2 \mathrm{~b}$ on clarity of information provided to the public female employees classified Very Good. Furthermore 2c questions about politeness, a gesture of hospitality female employees in serving the community shown by the statement that $11.1 \%$ of respondents said very good, $42.2 \%$ said good, $35.5 \%$ and $11.1 \%$ expressed Average stating Less Good, so it can be concluded that courtesy, hospitality attitude of female employees categorized Good. $2 \mathrm{~d}$ then to the question of the equal treatment to every community it serves declared Very 
Good 22.2\%, 62.2\% said good, and the remaining $15.5 \%$ declare Medium. So we can conclude from the four questions that talks about things that are visible on the service provided female employees at the Immigration Office Class II Bukittinggi in the public service can be said Good.

\section{Responsibility}

Responsiveness (Responsiveness), namely as responsiveness, willing to listen and respond to customers in an effort to satisfy the customer, for example, is able to provide true and correct information, do not show arrogance is busy and able to provide immediate relief. On Responsibility indicators or responsiveness of female employees in serving the community consists of four questions, which generates In answer respondents as in the following table:

Table 7 Response Female employees

\begin{tabular}{|c|c|c|c|c|c|c|c|c|c|c|c|c|}
\hline \multirow{3}{*}{$\begin{array}{c}\text { NO } \\
\text { Statement }\end{array}$} & \multicolumn{10}{|c|}{ alternative Answers } & \multirow{2}{*}{\multicolumn{2}{|c|}{ Total }} \\
\hline & \multicolumn{2}{|c|}{ Very good } & \multicolumn{2}{|c|}{ Good } & \multicolumn{2}{|c|}{ Moderate } & \multicolumn{2}{|c|}{ Less } & \multicolumn{2}{|c|}{ Very less } & & \\
\hline & $\mathrm{F}$ & $\%$ & $\mathrm{~F}$ & $\%$ & $\mathrm{~F}$ & $\%$ & $\mathrm{~F}$ & $\%$ & $\mathrm{~F}$ & $\%$ & $\mathrm{~F}$ & $\%$ \\
\hline $3 a$ & 14 & 31 & 31 & 69 & 0 & 0 & 0 & . & 0 & 0 & 45 & 100 \\
\hline $3 \mathrm{~b}$ & 11 & 24 & 34 & 76 & 0 & 0 & 0 & 0 & 0 & 0 & 45 & 100 \\
\hline $3 \mathrm{c}$ & 21 & 47 & 24 & 53 & 0 & 0 & 0 & 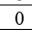 & 0 & 0 & 45 & 100 \\
\hline $3 d$ & 22 & 49 & \multirow{2}{*}{\multicolumn{2}{|c|}{$\frac{23}{62 \%}$}} & 0 & 0 & \multirow{2}{*}{\multicolumn{2}{|c|}{\begin{tabular}{l|l}
0 & 0 \\
$0,00 \%$
\end{tabular}}} & 0 & 0 & 45 & 100 \\
\hline Average & & & & \multicolumn{2}{|c|}{$0,00 \%$} & & & & \multicolumn{2}{|c|}{$100 \%$} \\
\hline
\end{tabular}

Source: processed data from excel 2007 Appendix 3

On the question about the attitude perceptive $3 \mathrm{a}$ and sprightly female employees to serve the public $31.1 \%$ of respondents expressed Very Good, and the remaining 68.9\% said good, it can be concluded that the attitude perceptive and sprightly female employees to serve the public categorized Good. For questions about the efforts of female employees $3 b$ satisfy the needs of the community expressed by the answers as much as $24.4 \%$ respondents stated Very Good, and the remaining $75.6 \%$ said Good. Further to question $3 \mathrm{c}$ on full and correct information given to the public views women employees of In answer $46.7 \%$ of respondents saying Very Good, and the remaining $53.3 \%$ said Good, it can be concluded that the information accurately and correctly given female employees to the people categorized Good. Then questions about the dexterity $3 \mathrm{~d}$ female employees in providing services to the community as much as $48.9 \%$ declare Very Good and the remaining $51.1 \%$ said Good. Of the four questions can be concluded that the power perceptive female employees in serving the people said Good.

\section{Assurance}

(Assurance), the ability of female employees in creating trust and confidence of customers through knowledge, courtesy and respect the customer's feelings, skills in providing information, the ability to provide security in utilizing the services offered. In Assurance indicator or guarantee given female employees in the public service consists of four questions, the which generates In answer the respondent as the following table:

Table 9 Guarantees issued by the employee Woman

\begin{tabular}{|c|c|c|c|c|c|c|c|c|c|c|c|c|}
\hline \multirow{3}{*}{$\begin{array}{c}\text { NO } \\
\text { Statement }\end{array}$} & \multicolumn{10}{|c|}{ alternative Answers } & \multirow{2}{*}{\multicolumn{2}{|c|}{ Total }} \\
\hline & \multicolumn{2}{|c|}{ Very good } & \multicolumn{2}{|c|}{ Good } & \multicolumn{2}{|c|}{ Moderate } & \multicolumn{2}{|c|}{ Less } & \multicolumn{2}{|c|}{ Very less } & & \\
\hline & $\mathrm{F}$ & $\%$ & $\mathrm{~F}$ & $\%$ & $\mathrm{~F}$ & $\%$ & $\mathrm{~F}$ & $\%$ & F & $\%$ & $\mathrm{~F}$ & $\%$ \\
\hline $4 a$ & 26 & 58 & 19 & 42 & 0 & 0 & 0 & 0 & 0 & 0 & 45 & 100 \\
\hline $4 \mathrm{~b}$ & 29 & 64 & 16 & 36 & 0 & 0 & 0 & 0 & 0 & 0 & 45 & 100 \\
\hline $4 \mathrm{c}$ & 11 & 24 & 21 & 47 & 13 & 28,89 & 0 & 0 & 0 & 0 & 45 & 100 \\
\hline $4 d$ & 3 & 6,7 & 25 & 56 & 14 & 31,11 & 3 & 6,67 & 0 & 0 & 45 & 100 \\
\hline Average & \multicolumn{2}{|c|}{$38,30 \%$} & \multicolumn{2}{|c|}{$45 \%$} & \multicolumn{2}{|c|}{$15,00 \%$} & \multicolumn{2}{|c|}{$1,70 \%$} & \multicolumn{2}{|c|}{$0,00 \%$} & \multicolumn{2}{|c|}{$100 \%$} \\
\hline
\end{tabular}

Source: processed data from excel 2007 Appendix 3

No. $4 \mathrm{a}$ on the question of public confidence in the services provided $57.8 \%$ said Very Good and $42.2 \%$ of respondents stated Neither can be categorized as public confidence in the services provided Very Good. For questions about the ability of female employees $4 \mathrm{~b}$ provide security services to the community as much as $64.4 \%$ said Very Good. And $35.6 \%$ said Good. So we can conclude female employee's ability to provide security services to the classified Very Good. Further to the question of female employees 4c shows good personality to the community looks of respondents expressed Very Good 24.4\%, 46.7\% said good, 28.9\% expressed Medium. From the respondents' answers can be concluded that female employees have shown a good personal to the public. Then to question $4 \mathrm{~d}$ about the pleasant service given to the public female employees can be seen from as much as $6.67 \%$ of respondents expressed Very Good, 55.6\% said good, $31.1 \%$ stated Medium, and $6.67 \%$ expressed Less Good , So we can conclude that female employees already provide pleasant service to the community. The fourth question of indicators Assurance or guarantee given to the community of women employees, we can conclude that the guarantee provided female employee class II Bukittinggi immigration office to the public in the form of public trust, security, good personal service and fun it can be considered good.

\section{Empaty}

Empathy, namely: the ability or willingness of female employees provide personal attention, such as being friendly, understanding the needs and care to its customers. Empathy is needed for continuity of service to the public in relation to passport services. Empathy includes individual attention given to public office, such as the ease to be served, the ability of employees to communicate with the public, and to understand the wants and needs of the community.

In indicator Empaty or concern for female employees to the community can be seen from the four questions, which resulted in the respondents' answers as in the following table:

Table 8 Employee Concern Women

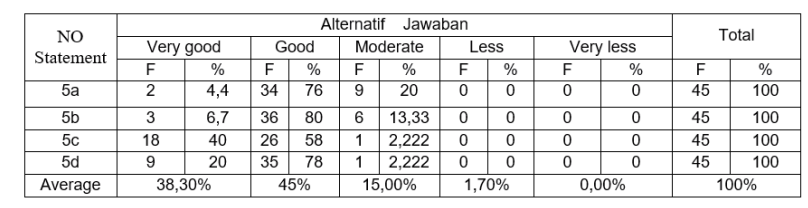

Source: processed data from excel 2007 Appendix 3

On the question about the willingness $5 \mathrm{a}$ female employees to give attention to the public $4.44 \%$ declared Very Good, $75.6 \%$ claimed Good and the remaining 20\% stated Medium. It can be concluded that the willingness of women to give attention categorized Good. 5b For questions about respect for people's sense visible from as much as $6.67 \%$ of respondents expressed Very Good, $80 \%$ said good, $13.3 \%$ stated Average, of the diversity of these answers can be concluded that the attitude of female employees appreciate the feeling of community is said Good. Further to $5 \mathrm{c}$ questions about the ability of female employees understand the needs of the community seen from the answers of respondents stated that $40 \%$ Very Good, Good 57.7\%, and 2.2\% declare Medium. So it can be concluded that the ability of women employees understand the needs of the community can be said Good. Then to $5 \mathrm{~d}$ questions about the ability of female employees to handle complaints from the public as much as $20 \%$ of respondents expressed Very Good, 77.8\% claimed Good and the remaining $2.2 \%$ Medium. 
So it can be concluded that the ability of women employees in dealing with complaints from the public can be said Good. Of the four indicator questions or concerns empathy female employees in the public service can be said Good.

To determine the professionalism of women in public service at the Immigration office class II Bukittinggi, it is necessary to set the interval percentage range as the author presented in Chapter III of the analyzes qualitative discussion of the problems first.

To determine the professionalism of women in the public service is used the ratio between the total score of the answers to the 20 item assessment that as many as 3,820 (attachment 3 ) with the highest total score is $5 \times 45 \times 20=4,500$. The result of the comparison is $3,820: 4,500=0,848$ or $0,848 \mathrm{x}$ $100 \%=84.8 \%$. If adjusted for the table 7 (Chapter III) of the assessment criteria, the value of $84.8 \%$ at a percentage interval range between $84-100$. These results show that the professionalism of women in public service at the Immigration office class II Bukittinggi Very Good.

Besides, it is supported by the results of interviews with male employees who say that the professionalism of women Very Good views of attitudes and daily behavior within the organization. That discipline in starting and completing the service, capable of doing the job which it is responsible, the attitude in delivering services to the public. Where female employees in the work to understand and implement well the role, duties and responsibilities in the field of immigration.

Meanwhile, prominent or dominant indicator of professionalism of women in public service at the Immigration office class II Bukittinggi determined by the sum total score from each of these indicators, as presented in the table 8 author as follows:

Table 10 Percentage Distribution Rate of Women in Public Service Professionalism Based Indicators Research

\begin{tabular}{cccc}
\hline No. & $\begin{array}{c}\text { Research } \\
\text { Indicator }\end{array}$ & $\Sigma$ & $\mathbf{\%}$ \\
\hline 1. & Reliability & $\mathbf{8 1 3}$ & $\mathbf{2 1 , 2 8}$ \\
2. & Tangible & 737 & 19,29 \\
3. & Responsibility & 788 & 20,63 \\
4. & Anssurance & 747 & 19,56 \\
5. & Empaty & 735 & 19,24 \\
& Total & $\mathbf{3 8 2 0}$ & $\mathbf{1 0 0}$ \\
\hline Source: Appendix 3 and processed by the author
\end{tabular}

Based on the above table that the most prominent indicators or dominant on the professionalism of women in the public service at the Immigration office Reliability class II Bukittinggi is because it has the biggest contribution, the total of $21.28 \%$. Based on respondents' assessment that the indicator Reliability (reliability/ expertise) most dominant because Capabilities female employees at the Immigration office has provided services in accordance with the expected community, such as the ability to promise keeping, problemsolving skills and the ability to minimize errors.

\section{Obstacles encountered the professionalism of Women in Public Service Immigration Office Class II Bukittinggi.}

In carrying out its performance many problems faced by female employees at the office of immigration class II
Bukittinggi obstacles encountered while the professionalism of women in the public service are:

\section{Impatience applicant/community to be served immediately}

Community generally believes that they are not satisfied with the services provided although it has sought as much as possible by the service providers. On one hand we should not blame either one of the services and the service receiver, a balance between the two in order to provide a quality service. from observations and interviews with the author of female employees at the immigration office class II Bukittinggi lack professional actually looks at people as recipients of services such as culture impatient waiting / queuing culture, they often came to the desk clerk before being served and always asked when her turn. By assigning a line starting at 07:30 to 12:00 hrs, some of them urged and pleaded with the officer to be served after 12:00 pm with various reasons for delays that are made against officers when all provisions of services based on standards of public service that is about timeliness has been governed by Constitution. But in fact the applicant nonetheless urged officers to be served on that day, while female employees themselves are serving people who are in front so that people are being served had felt the service provided is not satisfactory. With the lack professional society that is the burden of excessive work for women employees, especially in service registration of passport applicants should check the completeness of documents that require precision and concentration to avoid mistakes.

\section{Lack of public understanding about the procedures to follow}

In general, the public has to understand that any deal with the government to go through the procedures and meet the requirements of the service, in accordance with the needs of the type of service. Concerning the public's understanding of the service procedure is based on interviews with care workers woman that she was overwhelmed dealing with the public despite having been given understanding many times to them but they still went to the desk clerk that we often feel irritated despite the demands of a job that requires you to friendly, courteous, polite, smile in providing services, as such it makes the job professionalism reduced due to lack ikhlasan the rise of female employees in providing services to the community.

\section{The division of time between family and work}

Problems that occur not only seen from factors internal or within the working area, but also from external factors of the conflict seen him outside the work environment. As we know that women have the responsibility as a housewife and the responsibility as professional workers who are required to both, With so much of a role should women indicates that women have experienced a double burden in his life. Therefore women should be able to balance life between public and domestic spheres.

Based on the interview with a female employee at the immigration office class II Bukittinggi obstacles in his work is the division of time between work and family where both have a very important role, while having a problem outside the environment of the organization, for example children in a 
state of ill kodrad as their mother a woman carried away experience anxiety that lead to dedication to work is reduced.

\section{Factor of stress and fatigue}

Factors stress and fatigue can be seen from the observation of the author and the data supporting the results of an author interview with a female employee (Mrs. Susanti) where service officer looked exhausted by the number of personnel on the part of service personnel author of value is still less than the number of people who come take care of Immigration at the immigration office class II Bukittinggi, 75150 people per day so the clerk was overwhelmed dealing with the public, a lack of public understanding of the procedures that passed that increase the burden of work that can cause stress coupled with the problem of the division of time between the family and her work at the office. Resulting work to be done in a hurry and deadlines, the inner atmosphere and mood that is changing every day.

\section{Efforts are being made to overcome the obstacles encountered professionalism of women in public service at the immigration office class II Bukittinggi}

As for the efforts made to overcome the existing obstacles including the following:

\section{Implement a new line of service based systems}

Through the Directorate General of Immigration, Office of Immigration Class II Bukittinggi impose queue system for a passport with the new system. Head of Immigration Office Class II Bukittinggi Teguh Cahyono, BA said queue system for a passport with a referral to the new system of the Circular of the Director General of Immigration Number: IMIGR.01.01-0047 2016 on Passport Service Queue Republic of Indonesia with the system limits the time frame starting from $7: 30 \mathrm{pm}$ to $12: 00 \mathrm{pm}$ until. He explained that it is useful to realize the breakthrough publishing service passports meet the certainty principle, speed and ease. This system is much better than the previous system, the article before using a quota system. As a result, many people who are not well served. To that he added, restriction line with quota restrictions need to be converted into submission application for passports by the time limit.

Thus it is clear that the public's impatience was returned in self serviced each individual with clear rules can not be denied that the officers unprofessional service depends on the professionalism of the community itself.

\section{Provide an explanation and understanding}

Provide an explanation and understanding of the form of the knowledge of the immigration service procedures to the Security Officer / Security Guard, in order to facilitate the public to obtain information about the procedures and services can ease the workload of service personnel in dealing with the public. Service Officers so that jobs can run effectively and efficiently as well as to the point of service. Also supported with banners and strategic Diarea flamplet mounted close to the community to provide services in writing.

\section{Compensating}

Compensation is everything received by employees as remuneration for their work (Agussalim, M, 2011). As revealed by Mr. Ershad that:
"The provision of compensation to employees must be based on the consideration and must be adapted to the circumstances themselves as a female employee at the time he was working to serve the community, hear from his home that his son was sick and therefore he asked permission from his boss to go home early, in addition to the form of compensation given is permission for leave, maternity leave, sick leave, permission because there is a need and others ".

\section{Improving Human Relations / Human Relations between}

Human Relations is needed by everyone, especially employees of Class II Bukittinggi Immigration office because it will help women employees to communicate and understand the people who are nearby, which in akirnya can avoid or at least reduce miscommunication.

Human relations have narrow sense is an interaction in work situations in an organization whose purpose is to awaken a person to work, productively and have a decision.

This is where the role of a leader should be able to use the approach to human relationships with its employees in order to achieve the goals that have been formulated in a way to communicate that is human (s Tarma, 2010).

Form of connections made by its leaders that expressed by $\mathrm{Mr}$ Rahman Antoni Aziz is of harmonious relationships with female employees as did the laughter during the hours of rest in order to reduce the level of stress of the workload to which it aspires, and recreation and reflesing with all employees on time - certain time. Where he said "Recreation is aimed at creating a balance between work and rest, but it can develop relationships-relationships between superiors and subordinates as well as the relationship between employees, then it can be useful for health and employee satisfaction".

\section{Motivating Employees}

According Irham Fahmi (2013) The motive is related to the level of work done by a person in pursuit of a goal that is closely related to job satisfaction and performance.

Similar disclosed by Mrs. Ernawati as a leader and as a woman he was well aware of the task and its role as a leader and a humiliation of women (mother) where he uses instinct of motherhood in to motivate its employees to know their wishes, giving impetus to build and foster the spirit by helping them to achieve the ambitions and objectives, make them feel overlooked and needed, listen to complaints - their complaints, discuss the results they achieve and the disappointment they feel, giving kudos to them, trying to understand and maintain the image they.

\section{Implement Training}

Based on the results of interviews with Ms. Widia Nazinda about efforts exerted in addressing the constraints faced by the professionalism of women in public service, he says: "There is a training for all employees before he was placed there, given trials at its human resources if he is able or not, if it turns out he was able to be in further in that place but not necessarily able to jump remains in damping with people who can ". 
To enhance the quality of the employees, good skills, knowledge, expertise and mentally, given upgrading (upgraging) through training or exercises and other education.

\section{Education through Immigration Officer (DIKPIM)}

Dikpim is a special education immigration held to develop human resources who have the knowledge, skills, and attitudes and behavior commendable in implementing the tasks and functions of immigration where female employees have the opportunity to conduct a technical education in the field of immigration for 1 year.

Based on the results of author interviews with respondents about the efforts made to overcome the obstacles that exist on the professionalism of the women at the Immigration Office Class II Bukittinggi is: to implement a system of lines of new, give an understanding to the public about procedures, remuneration, increase the human relations, motivate employees, implement education immigration officials, and before engaging in work training first.

\section{CONCLUSIONS AND RECOMMENDATIONS}

\section{Conclusion}

As with Title skipsi that the author of "Women in Public Service Professionalism in the Office of Immigration Class II Bukittinggi". Based on the preceding discussion, the authors can provide some conclusions as follows:

Professionalism of women in the public service is the ability and talents of a woman in providing services to people who refer to the attitude and commitment of the profession to work on time and work cycle, so it may be reflected in everyday behavior in organizations.

Women professionalism at the Immigration office class II Bukittinggi in the immigration service categorized as very good. This is proven by $84.4 \%$ of respondents stated that by relying on the expertise, skills and knowledge will produce the readiness of employees in the implementation of immigration service that is disciplined in starting and completing the service, capable of doing the job which it is responsible, the attitude in delivering services to the community, Where female employees in the work to understand and implement well the role, duties and responsibilities in the field of immigration.

While indicators of prominent or dominant on the professionalism of women in public service at the immigration office class II Bukittinggi is reliability (reliability / membership) because it has the biggest contribution that amounted to $21.28 \%$.

Professionalism obstacles encountered by women in public service at the Immigration office class II Bukittinggi is:

1. unprofessional communities served as seen in the impatience in the community to be served immediately,

2. Lack of public understanding of the procedures that passed,

3. division of time between work and family conflict or so-called dual role of women

4. factors of stress and fatigue.
Efforts to overcome the obstacles encountered in the professionalism of women in public service at the Immigration office class II Bukittinggi is:

1. Applying a new line of service based systems

2. Provide explanations and understanding

3. Compensating

4. Improving human relations / human relations

5. Motivate employees

6. Implement Training

7. Through Education and Training (DIKPIM)

\section{Recommendation}

In order to increase the professionalism of Women in Public Service Immigration Office Class II Bukittinggi then suggested:

1. Professionalism Women in the immigration service as very good for it needs to be maintained and even further enhanced.

2. Adding an employee in the service of passport registration so that the number of people who come take care of their passports are not overwhelmed in serving the community.

3. In case the passport at the Immigration Office Class II Bukittinggi community should follow existing procedures, wait for the queue, follow the schedule that has been set, and avoid using the services of brokers.

4. For the public are advised to participate by filling in the complaint box on public complaints and criticism and constructive suggestions in order to obtain sufficient information for employees in improving their performance.

\section{Refferences}

Agussalim Manguluang 2011, Basics of Human Resource Management, Padang: Ekasakti Press.

Asrariyah, Siti, 2013. Professionalism Apparatus In the office of Head of Public Service Samarinda Ulu Kota Samarinda.

Boediono, B 2003 Excellent Service Tax. Jakarta: PT. Rineka Reserved.

Burhan Burgin, 2006, Qualitative Research Methods, Jakarta: PT Raja Grafindo.

Dwi Ambarsari, 2002. Public Policy and Participation of Women Cet. I Surakarta: Pattiro.

Darmadi Hamid, 2014. Educational and Social Research Methods, Jakarta: Alfabeta.

Horeapoetri, Arielle, 2004. Conversation ABOUT feminism vs. neoliberalism, Jakarta: Indonesia Debtwatch. Irham Fahmi, 2013. Organizational Behavior, Bandung: Alfabeta.

Imawan, Riswhanda, 1997. Professionalism political and Governmental Affairs, Medan. Indonesian Dictionary Third Edition, 2002. Jakarta: Balai Pustaka, p. 897

Kotler, Philip, 2002. Marketing Management in Indonesia: Analysis, Planning, Implementation and Control, Jakarta: Four Salemba.

Kurniawan, Agung, 2005. Public Service Transformation, Yogyakarta: Updates.

Kartini Kartono, 1989. Psychology of Women, Know Your Adolescent Girls and Adult women Bandung: Mandar Maju. 
Lijan Poltak Sinambela, et al, 2006. The Public Service Reform, Jakarta: Earth Literacy.

Murtadlo Muthahari, 1995. Women's rights Rights in Islam Jakarta: Lantern

Mansour Fakih, 2005. Analysis of Gender and Social Transformation Cet. IX Yogyakarta: Student Library.

Maskun, Sumitro, 1997. Professional Bureaucracy State Apparatus in Indonesia. Field.

Muliadi, Mappamiring, Ihyani Malik, 2015. Influence of Employee Work Professionalism The Effectiveness of Public Services at the Office of the District capil Disduk Bone, Muhammadiah Napier University.

Moenir, H.A.S. 2002. Management of Public Services in Indonesia. Jakarta: Earth Literacy.

Regulation of the Minister of Justice and Human Rights Affairs No. 17 of 2014 on the organization of education immigration officials Article 1 Chapter 1

Supriya, Dedi, 1999. Lifting the image and dignity of teachers. Yogyakarta: Adicipta Karya Nusa.

Syafiq Hasyim, 2005, Introduction to Feminism and Islamic Fundamentalism Cet. I. Yogyakarta: LKIS.
Sedermayanti. 2004. Good Governance (Good governance) Part Two: Building Sstem Performance Management to Increase Productivity Towards Good Governance (Good Governance). Bandung: Mandar Maju.

Sugiono, 2003. Research Methods, Jakarta: Alfabeta.

Sudjana, 1988.metode Statistics, Tarsgto: Bandung.

Tarma Sartima 2010, Training Courses Introduction to Administration, Padang: Faculty of Social and Political Sciences, University Ekasakti. Act No. 9 of 1992 on Immigration.

Zaitunah Subhan, 2004. Qodrat Women taqdir or Myth, Yogyakarta: Pustaka Pesantren.

http://www.pdii.lipi.go.id/Profesionalisme-karyawan-pdiilipi.htm Accessible on Sunday 15/06/2015 At $13.30 \mathrm{hrs}$.

Id.wikipedia.org/wiki/Pelayanan_Publik accessed 17/01/16 at $15: 21$

Id.wikipedia.org/wiki/Undang_Undang_Pelayanan_Publik accessed 01/17/16 21:00

Kemenpan, 2003. No. 63 of 2003, p, 7.

News Immigration Class II Bukittinggi, 2016.Berlakukan passport applicants queue, January 12 , accessible at $2: 24: 52 \mathrm{pm}$

Please cite this article in press as:

Agussalim M (2017) Professionalism Women in Public Service in Immigration Class Ii Bukittinggi', International Journal of Current Advanced Research, 6(3), pp. 2411-2420. http://dx.doi.org/10.24327/ijcar.2017. 2420.0019 